\title{
Analysing the effect of dietary prebiotics and probiotics on gut bacterial richness and diversity of Asian snakehead fingerlings using T-RFLP method
}

\author{
Mohammad Bodrul Munir ${ }^{1}$ (D) | Terence L. Marsh ${ }^{2}$ | Aimeric Blaud ${ }^{3}$ | \\ Roshada Hashim $^{4}$ | Wizilla Janti Anak Joshua ${ }^{1}$ | Siti Azizah Mohd Nor ${ }^{5}$
}

${ }^{1}$ Aquatic Resource Science and

Management, Faculty of Resource Science

and Technology, Universiti Malaysia

Sarawak, Kota Samarahan, Sarawak,

Malaysia

${ }^{2}$ Department of Microbiology and

Molecular Genetics, Biomedical \& Physical

Sciences, Michigan State University, East Lansing, Michigan,

${ }^{3}$ Department of Sustainable Agriculture Science, Rothamsted Research, Harpenden, UK

${ }^{4}$ Faculty of Science and Technology, Universiti Sains Islamic Malaysia, Bandar Baru Bangi, Malaysia

${ }^{5}$ Institute of Marine Biotechnology, Universiti Malaysia Terengganu, Kuala Terengganu, Malaysia

\section{Correspondence}

Mohammad Bodrul Munir, Aquatic Resource Science and Management, Faculty of Resource Science and Technology, Universiti Malaysia Sarawak, 94300 Kota Samarahan, Sarawak.

Email: hsjewel730@yahoo.com

Funding information

FRGS, Grant/Award Number: 203/

PBIOLOGI/6711308; USM Global

Fellowship

\begin{abstract}
This study was designed to evaluate the effects of three prebiotics ( $\beta$-glucan, galacto-oligosaccharide [GOS], mannan-oligosaccharide [MOS]) and two probiotics (Saccharomyces cerevisiae, Lactobacillus acidophilus) on the microbiome of snakehead during growth of fingerlings. In addition, the experiment evaluated the capacity of Channa striata fingerlings to retain the benefits derived from these supplements after withdrawal. Throughout the study, it was observed that supplementation with dietary prebiotics and probiotics led to significant $(p<0.05)$ change in gut bacterial profile and improvement in gut morphology. Terminal restriction fragment length polymorphism (T-RFLP) was used for the comparative analysis of gut communities and all 46 of the T-RFLP detected phylotypes were present in the Lactobacillus supplemented fish, while significantly fewer were detected in controls and other experimental supplement regimes. Histological studies and electron microscopy revealed that both the prebiotic and probiotic treated fish had significantly longer and wider villi and deeper crypts compared to the controls. The microvilli length, as evaluated with electron microscopy, was also longer in all treated fish compared to controls. Furthermore, this study is the first to report the absence of differences in sustaining the efficacies attained after intake of $\beta$-glucan, GOS, MOS and live yeast upon postfeeding with an unsupplemented feed, over a prolonged period.
\end{abstract}

\section{KEYWORDS}

gut bacterial richness and diversity, prebiotics, probiotics, snakehead fingerlings, terminal restriction fragment length polymorphism

\section{1 | INTRODUCTION}

Analysing the intestinal bacterial profile is one of the important factors in fish nutrition studies (Daniel et al., 2014; Lara-Flores, Olvera-Novoa, Guzmán-Méndez, \& López-Madrid, 2003; Moen, Saeed, Mohammad, \& Faranaz, 2011). The gastrointestinal (GI) tract of fish is known as the ecological nich (Austin \& Austin, 1987; Cahill, 1990; Denev, Staykov, Moutafchieva, \& Beev, 2009; Holben et al., 2002; Kim, Brunt, \& Austin, 2007; Llewellyn, Boutin,
Hoseinifar, \& Derome, 2015; Ringø et al., 2000; Ringø, Sperstad, Myklebust, Mayhew, \& Olsen, 2006; Ringø, Strøm, \& Tabachek., 1995) for a group of diverse selected beneficial bacteria derived from the surrounding aquatic environment, including water sediment and feed. The abundance of beneficial bacteria in the fish intestine is expected to influence fish growth and health (Cahill, 1990; Hoseinifar Khalili, \& Sun, 2016; Hoseinifar, Ahmadi, et al., 2016; MacFarlane, McLaughlin, \& G. Bullock., 1986). Moreover, a 
diverse microbial community has been correlated with a well-functioning Gl system (Nayak, 2010).

The Asian snakehead (Channa striata, Bloch, 1793) is one of the most economically important freshwater fish in Asia-Pacific region (Hossain, Latifa, \& Rahman, 2008; Jamsari, Tan, \& Siti-Azizah, 2011; Wee, 1982). It contains higher protein (16.2 g in $100 \mathrm{~g}$ muscle) compare to other freshwater fish such as gold fish or Carassius auratus and eel or Anguilla anguilla (Annasari, Aris, \& W., Yohanes, K., 2012) and has a high market value due to the high quality of flesh with low fat, less intramuscular spines and medicinal qualities (Haniffa \& Marimuthu, 2004). Extracts of its fins and scales are a good source of albumin for the people who have a deficiency of albumin (Haniffa \& Marimuthu, 2004). Therefore, the aquaculture production trend has increased 61.90\% from 2000 to 2012 (FAO, 2014) through semi-intensive, intensive culture and cage aquaculture practices. Frequently, when stocked at high density of snakehead fingerlings, the resulting accumulation of organic matter leads to deterioration of water quality and increases in diseases (Sinh \& Pomeroy, 2010).

Biologically, the fish grows slowly but growth can be accelerated using high-quality feed supplements (Hossain et al., 2008; Wee, 1982). Antibiotics can no longer be used to manage infection and fish health, to indirectly promote growth because of international food security regulations imposed by the Food and Agriculture Organization in 2006 (FAO, 2007). The FAO authority permits alternatives such as dietary prebiotics, probiotics, symbiotics, phytobiotics and other natural dietary supplements (Denev, 2008). Dietary prebiotics and probiotics can improve the growth performance, feed utilization, body indices (Hoseinifar, Safari, \& Dadar, 2017; Munir, Hashim, Abdul Manaf, \& Nor, 2016; Talpur, Munir, Marry, \& Hashim, 2014) nutrient protein digestibility, the expression of immune regulatory genes (Hoseinifar, Ahmadi, et al., 2016; Munir, Roshada, Yam, Terence, \& Azizah, 2016) and health status (Talpur et al., 2014) of snakehead. In fact, dietary prebiotics and probiotics provide direct beneficial effects on growth by improving intestinal microbial balance (Al-Dohail, Hashim, \& Aliyu, 2009; Dhanaraj et al., 2010) and by modifying the structure and function of the Gl tract in the fish (Akter, Sutriana, Talpur, \& Hashim, 2015; Amalia, Roshada, Nahid, \& Siti-Azizah, 2018; Carly et al., 2010; Jian et al., 2012; Ringø, Myklebust, Mayhew, \& Olsen, 2007). This study analysed the effect of dietary prebiotics and probiotics on gut bacterial richness and diversity of snakehead using terminal restriction fragment length polymorphism (T-RFLP) method. The T-RFLP is a technique for profiling microbial communities based on the position of a restriction site closest to a labelled end of an amplified gene (Christensen, Reynolds, Shukla, \& Reed, 2004; Coolen, Post, Davis, \& Forney, 2005; Davis et al., 2010; Nieminen et al., 2011).

\section{2 | MATERIALS AND METHODS}

\subsection{Experimental fish and husbandry conditions}

The study was conducted in Universiti Sains Malaysia (USM) Aquaculture Research Complex. A total of 4,800 C. striata fingerlings (av. wt. $22.40 \pm 0.06 \mathrm{~g}$ ) were selected from 10,000 master stocked snakehead fries and distributed equally (400 fish/ tank) in 12 outdoor rectangular cement tanks ( $2 \mathrm{~m} \times 1 \mathrm{~m} \times 0.5 \mathrm{~m})$. The fish were maintained in optimum condition with a natural photoperiod where the mean water temperature, $\mathrm{pH}$ and dissolved oxygen were $27.54 \pm 0.30^{\circ} \mathrm{C}, \quad 7.1 \pm 0.08$ and $6.1 \pm 0.18 \mathrm{mg} / \mathrm{L}$ respectively.

\subsection{Experimental diets and feeding trial}

Six experimental diets including the control contained $40 \%$ protein and $12 \%$ lipid (Table 1). Fish were fed the experimental diets in two phases. Phase 1 involved feeding six cohorts of fish experimental diets for 16 weeks while in Phase 2, all experimented fish were fed the non-supplemented control diet for 8 weeks. This was done to evaluate the efficacy of prebiotics and probiotic intake in Phase 1 and the reversibility of the supplementation. In both phases, fish were fed to satiation three times daily (i.e., early morning at 6.30 a.m., noon at 1 p.m. and late afternoon at 7 p.m.).

\section{3 | Viability of Lactobacillus acidophilus in the LBA diet}

The viability of L. acidophilus in LBA diet was performed three times, that is immediately after LBA diet preparation, two times (8 and 16 weeks) during storing at $-20^{\circ} \mathrm{C}$ temperature followed by the method described by Al-Dohail (2010); Wang, Yu, and Chou (2004) and Ishibashi, Tatematsu, Shimamura, Tomita, and Okonogi (1985).

\section{4 | Gut bacterial profile}

The gut bacterial profile in C. striata was conducted using T-RFLP, which was designed according to the method Cancilla, Powell, Hillier, and Davidson (1992), refined by Brunk's laboratory (Avaniss-Aghajani et al., 1996; Avaniss-Aghajani, Jones, Chapman, \& Brunk, 1994) described by Bruce (1997), Liu, Marsh, Cheng, and Forney (1997), Clement, Kehl, Bord, and Kitts (1998) and Marsh (2005). Twelve fish were randomly collected from each replicate tank making three groups of equal number of fish and were stocked in three black plastic tanks for $24 \mathrm{hr}$ without feeding. After $24 \mathrm{hr}$, the fish were sacrificed individually using ice block. The fish were dissected, removing undesired gut tissues such as liver, spleen and stomach. The intestine was carefully separated from the stomach by first tying it off at the junction of the stomach and intestine, cutting at the end of stomach before the tied area, thereby isolating materials in the intestine from contamination with stomach content. The exterior of the intestines was washed several times with sterile PBS buffer $(\mathrm{pH} 7.4)$ and blotted to remove the buffer. The intestines were cut into small pieces and mixed together. One replicate consisted of intestines of three fish. Cold environment was strictly maintained during this processes using ice blocks to protect the bacterial DNA from degradation. 
TABLE 1 Feed ingredients of the six experimental diet $(\mathrm{g} / \mathrm{kg}$, dry matter)

\begin{tabular}{|c|c|c|c|c|c|c|}
\hline Ingredients & Control & $\beta$-Glucan $0.2 \%$ & $\operatorname{GOS}^{\mathrm{b}} 1 \%$ & $\operatorname{MOS}^{\mathrm{c}} 0.5 \%$ & Live yeast ${ }^{\mathrm{d}} 1 \%$ & L. acidophilus ${ }^{\mathrm{e}} 0.01 \%$ \\
\hline Danish Fish Meal ${ }^{f}$ & 534 & 534 & 534 & 534 & 534 & 534 \\
\hline Korean Corn Starch & 340 & 340 & 340 & 340 & 340 & 340 \\
\hline Soybean oil & 60 & 60 & 60 & 60 & 60 & 60 \\
\hline Cellulose & 11 & 9 & 1 & 6 & 1 & 10.9 \\
\hline Minerals mix ${ }^{h}$ & 20 & 20 & 20 & 20 & 20 & 20 \\
\hline Supplement & 0 & 2 & 10 & 5 & 10 & 0.1 \\
\hline
\end{tabular}

Note. $\mathrm{CMC}=$ carboxymethyl cellulose.. ${ }^{\mathrm{a}} \beta$-Glucan $=$ Macrogard ${ }^{\circledR} . .{ }^{\mathrm{b}} \mathrm{GOS}=$ Galactooligosaccharides of Vivinal ${ }^{\circledR}$ GOS syrup, Friesland Campina Domo, the

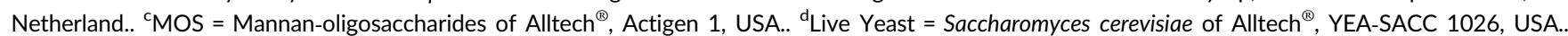
${ }^{\mathrm{e}} \mathrm{L}$. acidophilus = Lactobacillus acidophilus powder (Sigma ${ }^{\circledR}$ LBA).. ${ }^{\mathrm{f}}$ Danish Fish Meal $/ \mathrm{kg}=$ Crude Protein 746.6 and Crude Lipid 101.6.. ${ }^{\mathrm{g} V i t a m i n}$ Mix/kg $=$ Rovimix 6288, Roche Vitamins Ltd. Switzerland; Vit 50 million i.u., Vit 310 million i.u., Vit $_{\mathrm{E}} 130 \mathrm{~g}, \mathrm{Vit}_{\mathrm{B} 1} 10 \mathrm{~g}, \mathrm{Vit}_{\mathrm{B} 2} 25 \mathrm{~g}$, Vit $\mathrm{B}_{\mathrm{B} 6} 16 \mathrm{~g}, \mathrm{Vit}_{\mathrm{B} 12} 100 \mathrm{mg}$ Biotin 500 mg, Pantothenic acid 56 g, Folic Acid 8 g, Niacin 200 g, Anticake 20 g, Antioxidant 200 mg, Vit ${ }_{K 3} 10$ g and Vit 35 g.. hMineral Mix/kg = Calcium phosphate (monobasic) $397.65 \mathrm{~g}$, calcium lactate $327 \mathrm{~g}$, ferrous sulphate $25 \mathrm{~g}$, magnesium sulphate $137 \mathrm{~g}$, potassium chloride $50 \mathrm{~g}$, sodium chloride $60 \mathrm{~g}$, potassium iodide $150 \mathrm{mg}$, copper sulphate $780 \mathrm{mg}$, manganese oxide $800 \mathrm{mg}$, cobalt carbonate $100 \mathrm{mg}$, zinc oxide $1.5 \mathrm{~g}$ and sodium selenite $20 \mathrm{~g}$.

\section{5 | Genomic DNA extraction and PCR amplification}

The genomic DNA was extracted using PowerSoil ${ }^{\circledR}$ DNA isolation kit (Catalog No: 12888-S; MO BIO Laboratories Inc., CA, USA) according to the recommended vendor's protocol. The PCR amplification was performed using a conventional PCR machine (Model: ABI VERITI, Manufactured by Applied Biosystem, USA). The universal bacterial primers 63F (5'-CAG GCC TAA CAC ATG CAA GTC-3') (5' FAMlabelled) and 1389R (5'-ACG GGC GGT GTG TAC AAG-3') (unlabelled) (Aburto et al., 2009; Masanori, James, Kim, \& Marsh, 2013; Quaak \& Kuiper, 2011) were used to perform the 16S rDNA amplification. The PCR reaction was carried out using $i-T_{a q}{ }^{\text {TM }}$ plus DNA polymerase (Cat No. 25152; iNtRON Biotechnology, Inc. Manufacture) in a $50 \mu$ reaction volume containing $1.5 \mu$ DNTPs $(2.5 \mathrm{mMol})$, $5 \mu \mathrm{l} 10 \times$ Buffer, $1 \mu \mathrm{l}(1 \mu \mathrm{g})$ universal primers each, $0.5 \mu \mathrm{l}(2.5 \mathrm{U})$

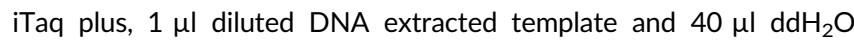
under the following cycle conditions: an initial denaturing step at $94^{\circ} \mathrm{C}$ for $3 \mathrm{~min}, 30$ cycles of denaturing step at $94^{\circ} \mathrm{C}$ for $30 \mathrm{~s}$, annealing at $55^{\circ} \mathrm{C}$ for $30 \mathrm{~s}$ and extension at $72^{\circ} \mathrm{C}$ for $1.5 \mathrm{~min}$. The final extension was performed at $72^{\circ} \mathrm{C}$ for $5 \mathrm{~min}$. The PCR mixture was prepared under freezing temperature using ice block chamber. After PCR, the amplification size was verified by gel electrophoresis using $1 \mathrm{~kb}$ ladder.

\subsection{Purification of PCR products and digestion}

The PCR products were purified using MEGAquick-spin ${ }^{\mathrm{TM}}$ Total Fragment DNA Purification Kit (iNtRON Biotechnology Manufacture) according to the Manufacturer's guideline. The purified PCR products were digested with Hhal (Product code R0139S; New England Biolabs) followed by the Manufacturer's guideline. The products were checked using gel electrophoresis.

\section{7 | T-RFLP fragment sequencing}

After gel electrophoresis, $15 \mu \mathrm{l}$ of digested DNA samples each was sent to Macrogen Inc., South Korea for T-RFLP sequencing. The service provider separated the DNA fragment (size standard 500LIZ) using $A B I$ 3730XL Genetic Analyzer automated sequencer (Applied Biosystem). Each feeding treatment had four biological replicates and each biological replicate had two technical replicates. The data were from samples taken at the end of 8 and 16 weeks in Phase 1 and at the end of Phase 2.

\section{8 | Comparative analysis of gut bacterial community profile}

The sequence data obtained from the service provider were retrieved using PEAKSCAN 3.1 software with the 500LIZ size standards. Therefore, the terminal restriction fragments (T-RFs) were binned with a $0.5 \mathrm{bp}$ interval and the T-RFs from 50 to $500 \mathrm{bp}$ were included in the analysis. T-Align software was used for the alignments of the fragment size.

\section{9 | Morphological measurement of intestine}

The villus length, width and crypt depth were determined using normal histological procedure following the method of Davenport in 1969, whereas the transmission electron microscopy (TEM) was used to determine the microvillus length following the method described by Lewis and Knight (1977).

\subsection{0 | Statistical analysis}

The bacterial richness in the gut of $C$. striata fingerlings for inclusion of dietary prebiotics and probiotics was estimated by counting the 
T-RFs number in each T-RFLP profile. The diversity of the bacterial communities took into account both species richness and species evenness. The species evenness indicates how close in population size of each bacterial species is in a community, or in this case, individual feeding trial and it was done using the Shannon index $\left(\mathrm{H}^{\prime}\right.$, Shannon, 1948). This involved three steps. (a) cluster analysis (illustrated through dendrogram) and data ordination using non-metric multi-dimensional scaling (nMDS) to visualize the result showing the difference between bacterial communities in the fish gut corresponding to different feeding treatments environment in the studied period; (b) test of significance difference using two-way ANOISM and two-way PERMANOVA; (c) finally, correlation between the bacterial community composition and the gut morphology correspond to the six feeding treatments over time.

To remove background noise from each T-RFLP profile for subsequent statistical analysis, the T-RFs that were below $0.5 \%$ (i.e., 0.005 ) were removed by setting a logical formula (Blaud, Diouf, Herrmann, \& Lerch, 2015). The normalized data were then square root transformed and a Bray-Curtis matrix was used for analysing similarities between samples and displaying the result using dendrogram (Culman, Gauch, Blackwood, \& Thies, 2008; Ramette, 2007) and nMDS plots. The significant difference between clusters of the dendrogram was tested using similarity profile (SIMPROF) analysis (999 permutations). The significant differences between feeding treatments with the time period were tested using two-way analysis of similarities (ANOSIM; 9,999 permutations). The significance levels, that is $p$ value, and $R$ value, that is the strength of the factors on samples were determined. $R$ values close to 1 indicated high separation between groups (e.g., between two feeding treatments or between two time period), while $R$ values close to 0 indicated no separation between groups (Clarke \& Gorley, 2001). Two-way permutational multivariate analysis of variance (PERMANOVA) was also used to test for difference in T-RFLP profiles between feeding treatments and time. All these analysis were carried out using PRIMER V6 statistical software (PRIMER-E Ltd., Plymouth, UK).

The gut morphological particulars (i.e., villus length, villus width, crypt depth and microvillus length) of $C$. striata were analysed using ANOVA to detect significant changes $(p<0.05)$ corresponding to six supplemented diets over time. Finally, the correlation between bacterial community composition (T-RFs or phylotypes) and the gut morphological particulars were analysed using Pearson correlation in SPSS.

\section{3 | RESULTS}

\section{1 | Gut bacterial profile}

\subsubsection{Bacterial community richness and evenness}

Supplementation with dietary prebiotics and probiotics enhanced the richness and evenness of the bacterial communities in the fish gut compared to the fish fed with the control (Figure 1). The restricted enzyme digestion generated different T-RFs (size standard 500LIZ) which representing distinct bacterial phylotypes found from the six feeding treatments. A total 49 different phylotypes were found (Figure 1). The T-RFs richness and evenness were significantly and systematically lower in the fish guts fed with the control (richness$31 \pm 4$, evenness $=3.41 \pm 0.13$, 8 weeks) than with any supplemented diet. The fish gut which was fed with the L.acidophilus showed the highest T-RFs richness and evenness (richness $=45 \pm 2$; evenness $=3.80 \pm 0.04,8$ weeks) in comparison to the fish fed with $\beta$-glucan, galacto-oligosaccharide (GOS) and mannan-oligosaccharide (MOS), regardless the feeding period, but was only slightly higher than fish fed with live yeast at 16 weeks. No significant differences in T-RFs richness and evenness were found at 8 weeks between $\beta$ glucan, GOS, MOS and live yeast (average richness $=41 \pm 2$, evenness $=3.70 \pm 0.03$ ) but at 16 weeks, live yeast was significantly $(p<0.05)$ higher than those three prebiotics. At the end of postfeeding treatments (i.e., 24 weeks), gut microbiomes fed with GOS were lower diversity compared to all the supplemented diets, and not significantly different from the control in richness and evenness.

\subsection{2 | Gut bacterial community composition}

The mean richness (i.e., the number of detected phylotypes) data of different bacterial community composition is presented in Figure 2. Fish fed with L. acidophilus supplemented diets carried the greatest number of distinct terminal fragments (49). A total of 11 T-RFs (i.e., 131.2, 137.34, 146.48, 157.79, 171, 199.69, 250.14, 327.03, 433.22, $455.39,489.22 \mathrm{bp})$ were absent in the control treated fish guts; and all of only four phylotypes (171, 199.69, 250.14 and $327.03 \mathrm{bp}$ ) were absent in other feeding treatments ( $\beta$-glucan, GOS, MOS, live yeast) compared to the fish gut treated with the L. acidophilus probiotic.

The cluster data analysis (Figure 3 ) revealed that the bacterial community compositions generated by T-RFLP were strongly affected by the inclusion of supplemented diets over the time period. According to the analysis, the bacterial community from the fish fed with the control diet shown the lowest similarity to the other treatments $(\sim 66 \%-75 \%$ similarity). The control fish at 8 weeks tended to group separately from the other weeks. The fish fed with L. acidophilus probiotic significantly $(p<0.05)$ clustered separately from the other supplemented diets (three prebiotics and probioticlive yeast), regardless the week of treatment, and showed $\sim 83 \%$ of similarity with these treatments. The remaining prebiotics treatments (i.e., $\beta$-glucan, GOS, MOS) and probiotic (i.e., live yeast) grouped together with high percentage of similarity ( 90\%) and showed inconsistent differences between the weeks of treatments. The nMDS plot (Figure 4) also showed similar community differences with the cluster analysis, where based on bacterial community composition, there were three groups: the control, LBA treated and all other treatments.

\subsection{3 | ANOISM and PERMANOVA analysis}

Two-way analysis of similarity (ANOISM) and PERMANOVA were used for determining the significant difference between the diets 

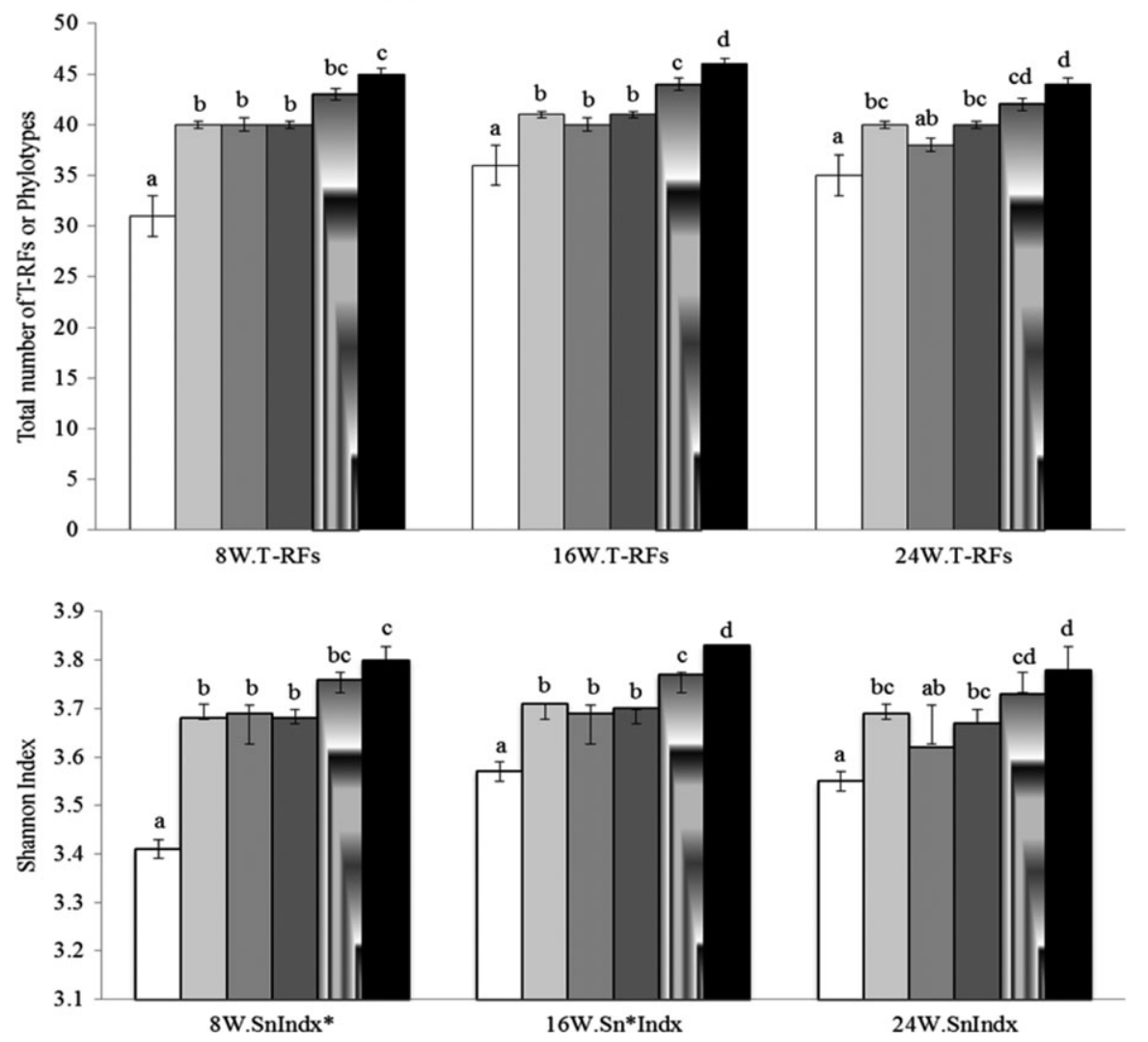

FIGURE 1 Variation in the number of T-RFs and the Shannon index from the bacterial community structure generated by T-RFLP from fish gut feed with six different diets over a 8, 16 (Phase 1) and 24 weeks (Phase 2) period. Mean values \pm standard errors $(n=3)$ are shown. Superscripts represent significant $(p<0.05)$ differences among the treatments tested

and periods. Two-way ANOSIM test revealed that diets had a strong effect on the bacterial community composition $(R \leq 1)$. The data demonstrated that the highest significance in comparison to the control feed was observed in the fish gut treated with LBA feed supplements, followed $\beta$-glucan, GOS, MOS and live yeast (Table 2). Between the two prebiotics (i.e., $\beta$-glucan to GOS; GOS to MOS and MOS to $\beta$-glucan), there was no pronounced difference (Table 2). Similar values were seen between beta-glucan and yeast; GOS and live yeast; and MOS and live yeast. A strong difference was observed between live yeast and LBA $(R=0.87)$. In this study, time period did not have a strong effect on the bacterial community structure $(R \leq 0.2) ; 8$ and 24 weeks showed the highest $R$ values $(R=0.2)$, and 8 versus 16 and 16 versus 24 showed similar $R$ values, 0.12 and 0.14 respectively.

Similar results were also found in PERMANOVA analysis. However, it also revealed the significance analysis result in three ways, that is between the diets, periods and the interaction of diets and periods. Table 3 represents the PERMANOVA analysis result of bacterial community composition affected by the comparison between diets, periods and their interactions. The result obtained from the PERMANOVA demonstrated that the highest significant difference between the control and supplemented diets was observed in the fish gut treated with LBA feed supplements, followed GOS, beta-glucan and live yeast. In comparisons with ANOISM, fish fed LBA contained the highest significant value for bacterial communities composition. Among the three prebiotics, there was not a strong effect. Although no strong effect was found between the three prebiotics and live yeast (probiotic), there was a significant difference between two probiotics amended fish (Table 3). The comparison among the rearing periods (week 8, 16 in the Phase 1 and the Phase 2 or post-feeding treatments period) and the interaction between the comparison of diets and rearing period did not show strong significant difference on the bacterial communities composition.

\section{2 | Relation between bacterial communities structure and gut morphology}

The study has revealed that inclusion of dietary prebiotics and probiotics profoundly influenced the gut microbiome. The villus length, villus width and crypt depth of the fish gut measured using light microscopic analysis were significantly increased $(p<0.05)$ in supplemented feeding treatments compared to control. Highest variation was observed in the fish fed with LBA (Table 4). There was no significant difference $(p<0.05)$ among three prebiotics ( $\beta$-glucan, GOS and MOS) feeding treatments but in several instances live yeast feeding treatments was very near to these three prebiotics. The microvillus lengths studied under TEM were found similar to villus length. The pearson revealed the correlations between the mean value of gut morphology and mean value bacterial communities richness in different feeding treatments over rearing periods. A positive correlation (Table 5) between the gut morphology and bacterial communities structure were found. There was very little significant 


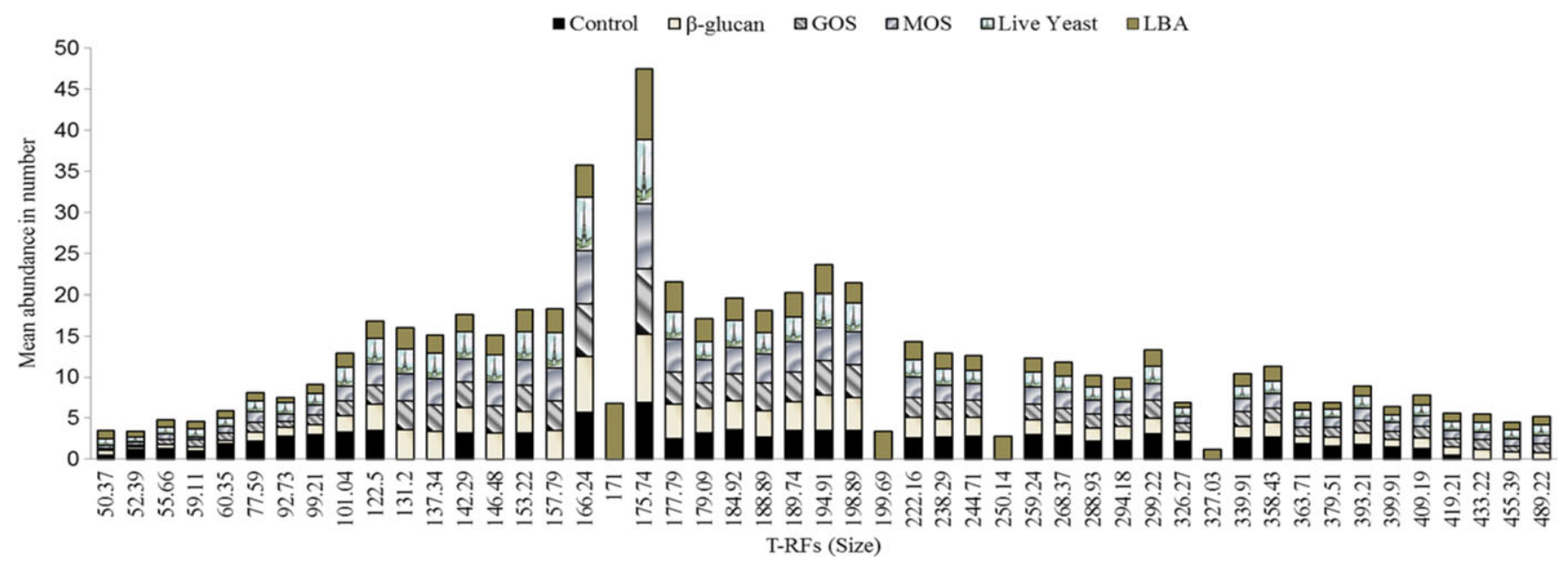

FIGURE 2 Mean abundance of T-RFs (size standard 500LIZ; size range 50-500 base pair) represents as phylotypes by six feeding treatments including control. The $\beta$-glucan, GOS, MOS, Live Yeast and LBA represent feed with beta-glucan, galactooligosaccharides, mannanoligosaccharides, Saccharomyces cerevisiae, Lactobacillus acodophilus feed supplements, respectively [Colour figure can be viewed at wileyonline library.com]

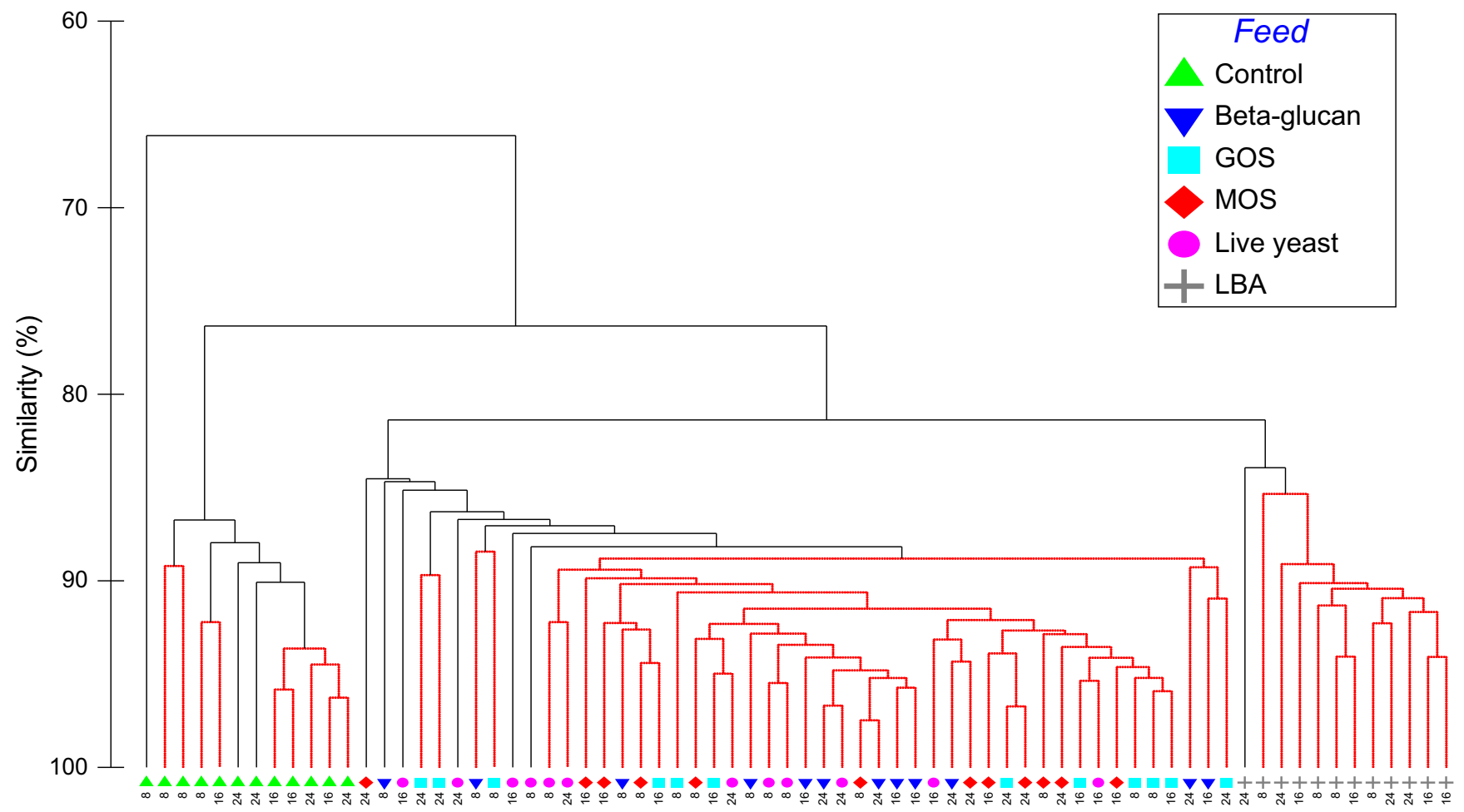

FIGURE 3 Dendrogram of the bacterial community composition from fish's gut that were feed with six different diets over a 8 and 16 weeks in Phase 1 and 24 weeks (following 8 weeks in Phase 2 or at the end of post feeding period). The numbers 8, 16, 24 indicate the period in week the fish are being feed. The dendrogram was produced using the group average linking method based on square root transformed data and Bray-Curtis similarity matrix. Red lines indicate clusters that are not significantly different $(p<0.05)$ using SIMPROF analysis (999 permutations) [Colour figure can be viewed at wileyonlinelibrary.com]

change in gut morphology between Phase 1 (at the end of 16 weeks) and Phase 2.

\section{4 | DISCUSSION}

In this study, the application of dietary prebiotics and probiotics over a prolonged period significantly changed the bacterial community composition. The cluster and nMDS analysis showed clear separation between all supplemented feed treatments and the control, which was further confirmed by SIMPROF, two-way ANOISM and twoway PERMANOVA analysis. Hence the supplemented feeding treatments likely affected the composition of bacterial communities either via direct or indirect effects of dietary probiotics or the dietary prebiotics respectively. This result agrees with the previous studies that 


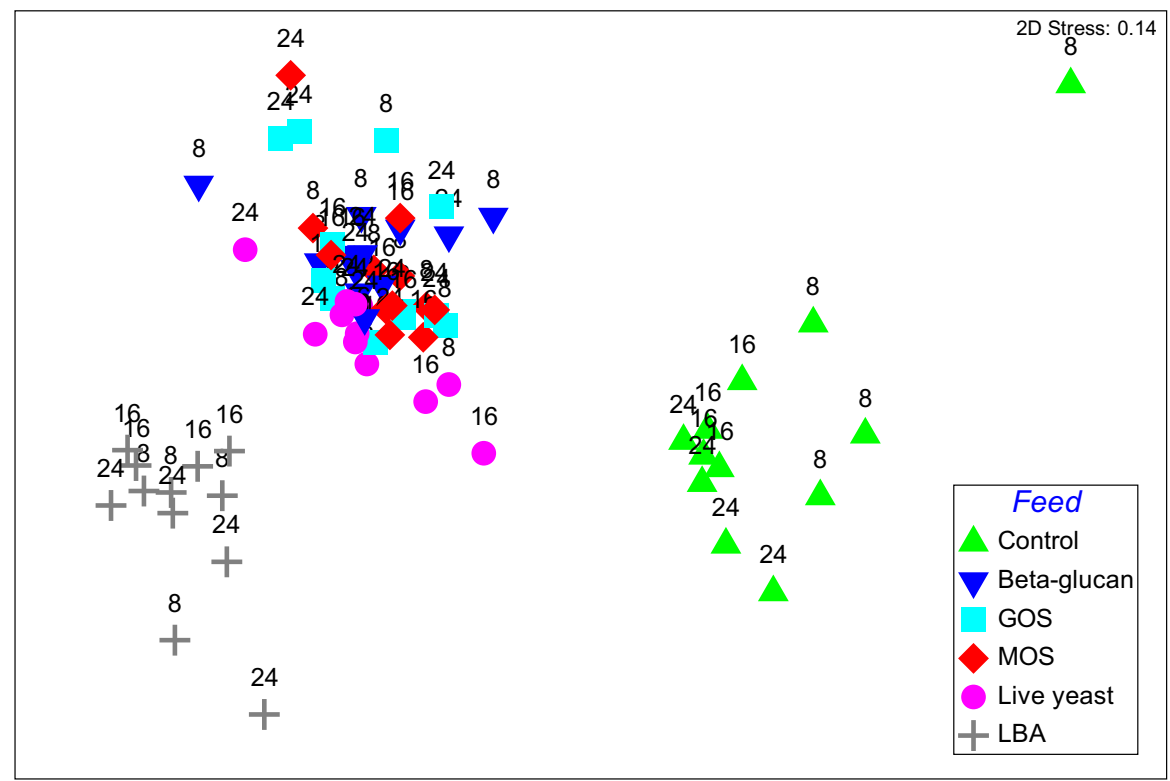

FIGURE 4 nMDS ordination of bacterial community composition from fish's gut that were feed with six different diets over a 8, 16 in Phase 1 and 24 weeks (following 8 weeks in Phase 2 or at the end of post feeding period). The numbers 8, 16, 24 indicate the period in week the fish are being feed. The nMDS was constructed from the data generated by T-RFLP that were square root transformed data and Bray-Curtis similarity matrix [Colour figure can be viewed at wile yonlinelibrary.com]
TABLE 2 Two-way analysis of similarities of the bacterial community structure generated by T-RFLP, testing differences between different fish diet and feeding period

\begin{tabular}{|c|c|c|c|}
\hline Factors & Comparison & $R$ value & $p$ Value \\
\hline \multirow[t]{15}{*}{ Diets } & Control versus $\beta$ glucan & 0.96 & 0.0002 \\
\hline & Control versus GOS & 0.94 & 0.0002 \\
\hline & Control versus MOS & 0.93 & 0.0002 \\
\hline & Control versus Live yeast & 0.93 & 0.0002 \\
\hline & Control versus LBA & 1.00 & 0.0002 \\
\hline & $\beta$ glucan versus GOS & 0.23 & 0.025 \\
\hline & $\beta$ glucan versus MOS & 0.19 & 0.129 \\
\hline & $\beta$ glucan versus live yeast & 0.19 & 0.007 \\
\hline & $\beta$ glucan versus LBA & 0.95 & 0.0002 \\
\hline & GOS versus MOS & 0.1 & 0.222 \\
\hline & GOS versus Live yeast & 0.28 & 0.0002 \\
\hline & GOS versus LBA & 0.97 & 0.0002 \\
\hline & MOS versus Live yeast & 0.17 & 0.0002 \\
\hline & MOS versus LBA & 0.93 & 0.0002 \\
\hline & Live yeast versus LBA & 0.87 & 0.0002 \\
\hline \multirow[t]{3}{*}{ Period } & Week 8 versus Week 16 & 0.12 & 0.006 \\
\hline & Week 8 versus Week 24 & 0.20 & 0.001 \\
\hline & Week 16 versus Week 24 & 0.14 & 0.008 \\
\hline
\end{tabular}

Note. Weeks 8 and 16 in the Phase 1 and Week 24 was in Phase 2 or at the end of post-feeding treatments period of the study.. GOS = galactooligosaccharides; LBA = Lactobacillus acidophilus; live yeast $=$ Saccha romyces cerevisiae; MOS = mannan-oligosaccharides.

evaluated the bacterial community composition of channel catfish, Pangasius hypophthalmus (Nahid, 2015) and small killifish, Fundulus heteroclitus (Givens, 2012).

The performance trend of six experimental diets on bacterial community composition was LBA $>$ live yeast $>\beta$-glucan $\geq$ MOS $\geq$ GOS $>$ control at the end of week 8 and 16 in Phase 1 . The reasons for increased performance with the experimental diets include the direct manipulation of intestinal microbial communities, suppression of pathogens, immunomodulation, stimulation of epithelial cell proliferation, differentiation, fortification of the intestinal barrier (Amalia et al., 2018; Hoseinifar, Mirvaghefi, Amoozegar, Merrifield, \& Ringø, 2015; Hoseinifar, Sharifian, Vesaghi, Khalili, \& Esteban, 2014; Thomas \& Versalovic, 2010; Yarahmadi, Kolangi Miandare, \& Hoseinifar, 2016) as well as meeting dietary requirements. The specific combination of positive effects at the molecular level may differ with the nature of each supplement. Nevertheless, the mode of action in each case led to increased performance with the greatest seen with LBA. This statement is supported by Nahid (2015) who conducted studies on the effect of prebiotic, MOS and probiotics, L. acidophilus at different doses on striped cat fish, Pangasianodon hypopthalmus. Earlier studies by Noh, Han, Won, and Choi (1994) and Bogut, Milaković, Bukvić, Brkić, and Zimmer (1998) on common carp fingerlings showed similar results. The study also evaluated the viability of $\mathrm{L}$. acidophilus in LBA diet during frozen $\left(-20^{\circ} \mathrm{C}\right)$ storage (Table 6). This study also indicated that there were no significant differences among the three prebiotics on bacterial community composition in the intestine over the time period. This is likely due to the unique stimulating and immunomodulatory characteristic of the three prebiotics tested that facilitated the growth of beneficial bacteria in the GI tract. Furthermore, these two attributes make the prebiotics a gut microflora management tool of fish (Gibson, 2008). Prebiotics are non-digestible dietary fibre comprising of non-starch polysaccharides such as cellulose and many other plant components such as pectins, dextrins, lignins, $\beta$-glucans (Philippe \& Sylvie, 2010). Numerous reports in the literature have observed that diets containing prebiotics have a stimulation effect of species belonging to the genera Bacteroides, Bifidobacterium, Ruminococcus, Eubacterium and Lactobacillus (Nino, 2013; Snart, Bibiloni, \& Grayson, 2006). Prebiotics can avert the attachment and colonization of harmful bacteria in the digestive tract (Gültepe, Salnur, Hossu, \& Hisar, 2011; 
TAB LE 3 PERMANOVA analysis ( $F$ value and $p$ value) of bacterial composition in fish gut with control (Permutation $N=9,999)$. Three times, that is week 8 , week 16 and the post-feeding or week 24 were togetherly analysed by PERMANOVA

\begin{tabular}{|c|c|c|c|c|c|c|}
\hline \multirow[b]{2}{*}{ Comparison diets } & \multicolumn{2}{|l|}{ Diets $(D)$} & \multicolumn{2}{|c|}{ Period or time $(T)$} & \multicolumn{2}{|c|}{$\begin{array}{l}\text { Interaction between } D \text { and } \\
T\end{array}$} \\
\hline & $F$ value & $p$ value & $F$ value & $p$ value & $F$ value & $p$ value \\
\hline Control versus GOS & 41.34 & 0.0001 & 3.63 & 0.009 & 2.37 & 0.05 \\
\hline Control versus MOS & 39.24 & 0.0001 & 2.46 & 0.05 & 2.29 & 0.06 \\
\hline$\beta$ glucan versus GOS & 1.79 & 0.04 & 2.12 & 0.002 & 1.27 & 0.19 \\
\hline$\beta$ glucan versus MOS & 1.87 & 0.03 & 1.22 & 0.206 & 0.84 & 0.71 \\
\hline$\beta$ glucan versus live yeast & 2.80 & 0.0003 & 0.97 & 0.52 & 1.00 & 0.46 \\
\hline$\beta$ glucan versus LBA & 25.34 & 0.0001 & 1.12 & 0.35 & 1.13 & 0.30 \\
\hline MOS versus Live yeast & 2.56 & 0.0002 & 1.22 & 0.16 & 0.97 & 0.53 \\
\hline MOS versus LBA & 26.86 & 0.0001 & 0.81 & 0.514 & 1.70 & 0.12 \\
\hline Live yeast versus LBA & 21.93 & 0.0001 & 1.29 & 0.24 & 1.05 & 0.35 \\
\hline
\end{tabular}

Note. GOS = galactooligosaccharides; LBA = Lactobacillus acidophilus; live yeast = Saccharomyces cerevisiae; MOS = mannan-oligosaccharides.

TABLE 4 Gut morphology (mean $\pm S D$ ) changed for inclusion of dietary prebiotics and probiotics

\begin{tabular}{|c|c|c|c|c|c|c|c|}
\hline Gut particulars & Phase & Control & $\beta$-glucan & GOS & MOS & Live yeast & LBA \\
\hline \multirow[t]{2}{*}{ Villus length in $\mathrm{m}$} & P $1^{*}$ & $344.23 \pm 2.4^{a}$ & $548.86 \pm 2.3^{\mathrm{b}}$ & $542.37 \pm 10.8^{b}$ & $540.09 \pm 6.1^{\mathrm{b}}$ & $652.27 \pm 2.0^{c}$ & $709.74 \pm 8.0^{d}$ \\
\hline & $\mathrm{P} 2 \dagger$ & $415.92 \pm 6.1^{\mathrm{a}}$ & $635.58 \pm 1.1^{c}$ & $619.76 \pm 8.7^{\mathrm{b}}$ & $523.14 \pm 8.8^{b}$ & $725.66 \pm 2.8^{d}$ & $908.30 \pm 9.6^{\mathrm{e}}$ \\
\hline Villus width in $\mathrm{m}$ & $\mathrm{P} 2 \dagger$ & $87.62 \pm 0.9^{a}$ & $132.76 \pm 8.5^{\mathrm{cd}}$ & $113.58 \pm 4.6^{c}$ & $124.90 \pm 3.6^{c}$ & $137.21 \pm 7.1^{\mathrm{d}}$ & $146.73 \pm 9.1^{\mathrm{e}}$ \\
\hline Crypt depth in $\mathrm{m}$ & P $1^{*}$ & $45.71 \pm 3.3^{\mathrm{a}}$ & $60.75 \pm 0.2^{b}$ & $60.06 \pm 1.9^{b}$ & $59.94 \pm 1.4^{\mathrm{b}}$ & $61.90 \pm 2.0^{\mathrm{b}}$ & $74.07 \pm 2.7^{c}$ \\
\hline Microvillus length in $\mathrm{m}$ & $P 2 \dagger$ & $1.16 \pm 0.07^{a}$ & $1.62 \pm 0.02^{\mathrm{bc}}$ & $1.58 \pm 0.3^{b}$ & $1.59 \pm 0.02^{b}$ & $1.67 \pm 0.03^{\mathrm{cd}}$ & $1.71 \pm 0.03^{d}$ \\
\hline
\end{tabular}

Note. Superscripts represent significant $(p<0.05)$ differences among the treatments tested.. GOS = galactooligosaccharides; LBA = Lactobacillus acidophilus; live yeast $=$ Saccharomyces cerevisiae; $\mathrm{MOS}=$ mannan-oligosaccharides. ${ }^{*} \mathrm{P} 1=$ Phase 1 where fish were fed with dietary prebiotics and probiotics.. $†$ P 2 = Phase 2 where treated fish were fed with non-supplemented feed.

Rodriguez-Estrada, Satoh, Haga, Fushimi, \& Sweetman, 2013) and create an opportunity for attachment of the beneficial bacteria in the GI tract of fish which consequently promotes the selective colonization of beneficial bacteria such as lactic acid bacteria, bifidobacteria (Wu et al., 2014) and exclude that of harmful bacteria. Similar conclusions were drawn by Menne, Guggenbuhl, and Roberfroid (2000); Buddington, Williams, Chen, and Witherly (1996); Gibson, Beatty, Wang, and Cummings (1995); and Mitsuoka, Hidaka, and Eida (1987).

In contrast, dietary probiotics (live bacteria or yeast) may have the ability to adhere to intestinal cells and mucus directly immediately after consumption, resulting in rapid colonization of the $\mathrm{Gl}$ tract (FAO, 2007; Gibson \& Wang, 1994; Kruger \& Mann, 2003; Mäyrä-Mäkien \& Bigret, 1993). This study indicated that the probiotics made the greatest difference in performance compared to the prebiotics. This is likely if the probiotic bacteria successfully colonized the intestine and then integrated into the host microbiome to exert a long-term effect (Waché et al., 2006). On the other hand, the effects of prebiotics are more indirect and dependent on a positive response of populations already present in the gut (Bouhnik et al., 1997; Gibson et al., 1995; Kleesen, Sykura, Zunft, \& Blaut, 1997). In this study, both performance and bacterial diversity were better with the probiotics treatment compared to the control and that of prebiotics. A total of 46 different T-RFLP phylotypes were obtained in this study. The LBA amended fish intestine carried all 46 phylotypes and four phylotypes were absent from the other four supplemented diets (three prebiotics $-\beta$ glucan, GOS and MOS; and one probiotic-live yeast). Eleven phylotypes were absent from the 
TABLE 5 Pearson correlation (near to 1 = positive correlation; near to -1 = negative correlation) between gut morphology and bacterial communities

\begin{tabular}{|c|c|c|c|c|c|c|c|c|c|c|c|c|}
\hline & 16 Weeks & T-RF & VL & vw & CD & MVL & 24 Weeks & T-RF & VL & vW & $C D$ & MVL \\
\hline \multirow[t]{5}{*}{ Pearson Correlation } & T-RF & & & & & & $\mathrm{T}-\mathrm{RF}$ & & & & & \\
\hline & VL & $0.985^{*}$ & & & & & $\mathrm{VL}$ & $0.908^{*}$ & & & & \\
\hline & VW & $0.966^{*}$ & $0.987^{*}$ & & & & VW & $0.976^{*}$ & $0.869^{*}$ & & & \\
\hline & $C D$ & $0.941^{*}$ & $0.953^{*}$ & $0.986^{*}$ & & & $\mathrm{CD}$ & $0.931^{*}$ & $0.856^{*}$ & $0.958^{*}$ & & \\
\hline & MVL & $0.857^{*}$ & $0.912^{*}$ & $0.916^{*}$ & $0.898^{*}$ & & MVL & $0.889^{*}$ & $0.798^{*}$ & $0.943^{*}$ & $0.982^{*}$ & \\
\hline \multirow[t]{5}{*}{ Sig. (1-tailed) } & T-RF & & & & & & T-RF & & & & & \\
\hline & $\mathrm{VL}$ & 0.000 & & & & & VL & 0.006 & & & & \\
\hline & VW & 0.001 & 0.000 & & & & VW & 0.000 & 0.012 & & & \\
\hline & $C D$ & 0.003 & 0.002 & 0.000 & & . & $C D$ & 0.003 & 0.015 & 0.001 & & \\
\hline & MVL & 0.015 & 0.006 & 0.005 & 0.008 & & MVL & 0.009 & 0.028 & 0.002 & 0.000 & \\
\hline
\end{tabular}

Note. $\mathrm{CD}=$ crypt depth; $\mathrm{MVL}=$ microvillus length; $\mathrm{T}-\mathrm{RF}=$ terminal restriction fragment as phylotype; $\mathrm{VL}=$ villus length; $\mathrm{VW}=$ villus width.. ${ }^{*} \mathrm{Correlation}$ is significant at the 0.05 level.

TAB LE 6 Viability of Lactobacillus acodophilus in LBA supplemented diet

\begin{tabular}{ll|} 
Validation period & CFU $10^{8}$ \\
\hline Initial day & $8.71 \pm 0.07$ \\
\hline After 8 weeks & $8.35 \pm 0.12$ \\
\hline After 16 weeks & $7.15 \pm 0.12$
\end{tabular}

unsupplemented diet or control. As the control diet did not contain any supplementation, the study assumed that control fish intestine carried indigenous bacteria. The absence of phylotypes in control treated intestine proves that the supplemented diets had an ability to manipulate the indigenous bacteria living in the intestine.

Changes of the intestine bacterial community composition and enhanced growth (Munir, Hashim, et al., 2016; Munir, Roshada, et al., 2016) may be linked the morphology of intestine. Colonization mechanism of the epithelial tissues allows the harmful bacteria to colonize, is considered an essential step in the infection of fish (Spring, Wenk, Dawson, \& Newman, 2000). The application of dietary prebiotics and probiotics can effectively reduce the colonization of these pathogenic bacteria (Kim, Seo, Kim, \& Paik, 2011; Ng, Hart, Kamm, Stagg, \& Knight, 2009). This study suggests that with a control diet there were stresses on the epithelial tissue that resulted in reduced villi and microvilli size. The addition of pre- or probiotics alleviated these stressors and produced significantly more robust villi and microvilli. The precise mechanism for this is unknown but it is consistent with reducing access of pathogens to intestinal epithelium. The enhanced intestinal morphology increased the absorptive surface area leading to better growth performance in fish (Hoseinifar et al., 2015, 2014 ; Munir, Hashim, et al., 2016; Munir, Roshada, et al., 2016; Yarahmadi et al., 2016). The results were very similar to T-RFLP data analysis where the performance of LBA supplemented diets produced the greatest difference in epithelial morphology.

At the end of Phase 2 of the present study, the performance trend of bacterial community composition changed slightly, but the result derived from the supplemented diets was still higher than the control treated intestine. It is now well documented that the taxonomic composition of vertebrate gut microflora is affected positively by the host dietary intake (Muegge et al., 2011; Wu et al., 2011). Consistently, the present investigation also demonstrated a concurrent increase in intestine bacterial richness and evenness corresponding to the dietary prebiotics and probiotics at the end of Phase 1. Consistently, the present investigation also demonstrated a concurrent increase in intestine bacterial richness and evenness corresponding to the dietary prebiotics and probiotics at the end of Phase 1. During this period, the fish were fed regularly with the formulated diets. The effects of dietary prebiotics and probiotics on community diversity and evenness were maintained during the postfeeding trial period where the treated fish were fed with the control diet only. The details of this extended effect of pre- and probiotics require additional studies.

\section{ACKNOWLEDGMENTS}

The authors would like to express the thanks to FRGS (Ref: 203/PBIOLOGI/6711308) as well as the USM Global Fellowship for the financial support to conduct the research. Special thanks go to FRI Pulau Sayak, Kedah for proving the facility of experimental diets preparation, AllTech ${ }^{\circledR}$ for providing free of cost (for research) of the Bioactin and YaaSac, as well as to similar to FriedlandCampina Domo ${ }^{\circledR}$ for Vivinal GOS Syrup and Bio-Origin for Macroguard ${ }^{\circledR} \beta$-glucan.

\section{ORCID}

Mohammad Bodrul Munir (iD http://orcid.org/0000-0003-1162-1702

\section{REFERENCES}

Aburto, A., Fahy, A., Coulon, F., Lethbridge, G., Timmis, K. N., Ball, A. S., \& McGenity, T. J. (2009). Mixed aerobic and anaerobic microbial communities in benzene-contaminated groundwater. Journal of Applied Microbiology, 106, 317-328. 
Akter, N. M., Sutriana, A., Talpur, A. D., \& Hashim, R. (2015). Dietary supplementation with mannan oligosaccharide influences growth, digestive enzymes, gut morphology, and microbiota in juvenile striped catfish. Pangasianodon Hypophthalmus. Aquaculture International, 24 (1), 127-144. https://doi.org/10.1007/s10499-015-9913-8

Al-Dohail, M. A., Hashim, R., \& Aliyu, P. M. (2009). Effects of the probiotics, Lactobacillus acidophilus, on the growth performance, haematology parameters and immunoglobulin concentration in African Catfish (Clarias gariepinus, Burchell 1822) fingerling. Aquaculture Research, 40, 1542-1652.

Al-Dohail, M. A. (2010). Effect of probiotic, Lactobacillus acidophilus on pathogenic bacteria, growth, hematological parameters and histopathology of African catfish, Clarias gariepinus. A PhD thesis under School of Biological Science in Universiti Sains Malaysia, pp. 1-201.

Amalia, S., Roshada, H., Nahid, A., \& Siti-Azizah, N. (2018). Galactooligosaccharide and a combination of yeast and $\beta$-glucan supplements enhance growth and improve intestinal condition in striped catfish Pangasianodon hypophthalmus fed soybean meal diets. Fisheries Science Fisheries Science, 84(3), 523-533. https://doi.org/10.1007/ s12562-018-1195-4

Annasari, M., Aris, W. M., \& Yohanes, K. (2012). Albumin and zinc content of snakehead fish (Channa striata) extract and its role in health.. IEESE International Journal of Science and Technology (IJSTE), 1(2), 1-8.

Austin, B., \& Austin, D. A. (1987). Bacterial fish pathogens: Disease in farmed and wild fish. New York, NY: E. Horwood; Halsted Press.

Avaniss-Aghajani, E., Jones, K. A. H., Aronson, T., Glover, N., Boian, M., Froman, S., \& Brunk, C. F. (1996). Molecular technique for rapid identification of Mycobacteria. Journal of Clinical Microbiology, 34, 98102.

Avaniss-Aghajani, E., Jones, K., Chapman, D., \& Brunk, C. (1994). A molecular technique for identification of bacteria using small subunit ribosomal RNA sequences. BioTechniques, 17, 144-149.

Blaud, A., Diouf, F., Herrmann, A. M., \& Lerch, T. Z. (2015). Analysing the effect of soil organic matter on bacterial communities using T-RFLP fingerprinting: Different methods, different stories? Biology and Fertility of Soils, 51(8), 959-971. https://doi.org/10.1007/s00374-015-1041-0

Bloch, M. E. (1793). Naturgeschichte der Ausländischen fische, 7. Berlin, Germany: Morino and Co. 144 pp.

Bogut, I., Milaković, Z., Bukvić, Z., Brkić, S., \& Zimmer, R. (1998). Influence of probiotic (Streptococcus faecium M74) on growth and content of intestinal microflora in carp (Cyprinus carpio). Czech Journal of Animal Science, 43, 231-235.

Bouhnik, Y., Flourie, B., D'Agay-Abensour, L., Pochart, P., Gramet, G., Durand, M., \& Rambaud, J. C. (1997). Administration of transgalactooligosaccharides increases faecal bifidobacteria and modifies colonic fermentation metabolism in healthy humans. Journal of Nutrition, 127, $444-448$.

Bruce, K. D. (1997). Analysis of mer gene subclasses within bacterial communities in soils and sediments resolved by fluorescent-PCR-restriction fragment length polymorphism profiling. Applied and Environment Microbiology, 63, 4914-4919.

Buddington, R. K., Williams, C. H., Chen, S. C., \& Witherly, S. A. (1996). Dietary supplement of neosugar alters the fecal flora and decreases activities of some reductive enzymes in human subjects. The American Journal of Clinical Nutrition, 63, 709-716. https://doi.org/10. 1093/ajcn/63.5.709

Cahill, M. M. (1990). Bacterial flora of fishes: A review. Microbial Ecology, 19, 21-41.

Cancilla, M. R., Powell, I. B., Hillier, A. J., \& Davidson, B. E. (1992). Rapid genomic fingerprinting of Lactococcus lactis strains by arbitrarily primed polymerase chain reaction with $32 \mathrm{P}$ and fluorescent labels. Applied and Environment Microbiology, 58, 1772-1775.

Carly, L. D., Daniel, L. M., Dominic, P. B., Simon, J. D., Jan, R. F., \& Katie, E. A. (2010). Effect of dietary Bacillus spp. and mannan oligosaccharides (MOS) on European lobster (Homarus gammarus L.) larvae growth performance, gut morphology and gut microbiota. Aquaculture, 304(1-4), 49-57.

Christensen, J. E., Reynolds, C. E., Shukla, S. K., \& Reed, K. D. (2004). Rapid molecular diagnosis of Lactobacillus bacteremia by terminal restriction fragment length polymorphism analysis of the 16S rRNA gene. Clinical Medicine \& Research, 2, 37-45.

Clarke, K. R., \& Gorley, R. N. (2001). Primer v5: User manual/tutorial. Plymouth, UK: Primer-E Ltd.

Clement, B. G., Kehl, L. E., De Bord, K. L., \& Kitts, C. L. (1998). Terminal restriction fragment pattern (TRFPs), a rapid, PCR-based method for the comparison of complex bacterial communities. Journal of Microbiol Methods, 31, 135-142.

Coolen, M. J., Post, E., Davis, C. C., \& Forney, L. J. (2005). Characterization of microbial communities found in the human vagina by analysis of terminal restriction fragment length polymorphisms of 16S rRNA genes. Applied and Environmental Microbiology, 71, 8729-8737.

Culman, S. W., Gauch, H. G., Blackwood, C. B., \& Thies, J. E. (2008). Analysis of TRFLP data using analysis of variance and ordination methods: A comparative study. Journal of Microbiological Methods, 75, 55-63.

Daniel, I. B., Lisa, K. S., Philipp, E. H., Christian, L. L., Rob, K., Gregory, J. C., \& Richard, S. (2014). Individuals' diet diversity influences gut microbial diversity in two freshwater fish (threespine stickleback and Eurasian perch). Ecology Letters, 17, 979-987.

Davis, E., Rehberger, J., King, M., Brown, D. C., Maxwell, C. V., \& Rehberger, T. (2010). Characterization of gastrointestinal microbial and immune populations post-weaning in conventionally-reared and segregated early weaned pigs. Livestock Science, 133, 92-94.

Denev, S. A. (2008). Ecological alternatives of antibiotic growth promoters in the animal husbandry and aquaculture. DSc thesis, Department of Biochemistry Microbiology, Trakia University Stara Zagora, Bulgaria (pp. 294).

Denev, S., Staykov, Y., Moutafchieva, R., \& Beev, G. (2009). Microbial ecology of the gastrointestinal tract of fish and the potential application of probiotics and prebiotics in finfish aquaculture. Aquaculture Research, 1, 1-29.

Dhanaraj, M., Haniffa, M. A., Arun, S., Jesu, A. A., Muthu, R. C., Seetharaman, S., \& Arthimanju, R. (2010). Effect of probiotics on growth performance of koi carp (Cyprinus carpio). Journal of Applied Aquaculture, 22, 202-209.

FAO Technical Meeting Report (2007). FAO Technical Meeting on Prebiotics, September, 15-16, 2007.

FAO. Food and Agriculture Organization (2014). The state of world fisheries and aquaculture 2014 (pp. 223). Rome, Italy: FAO.

Gibson, G. R. (2008). Prebiotics as gut microflora management tools. Journal of Clinical Gastroenterology, 42(Suppl. 2), S75-S79. https://doi. org/10.1097/MCG.0b013e31815ed097

Gibson, G. R., Beatty, E. R., Wang, X., \& Cummings, J. H. (1995). Selective stimulation of bifidobacteria in the human colon by oligofructose and inulin. Gastroenterology, 108, 975-982. https://doi.org/10.1016/ 0016-5085(95)90192-2

Gibson, G. R., \& Wang, X. (1994). Bifidogenic properties of different types of fructo-oligosaccharides. Food Microbiology, 11, 491-498.

Givens, E. C. (2012). Altering the balance: The effects of modified diet on the gut microflora of Fundulus heterocutus and Lagodon rhomboides. A doctoral thesis of Graduate School in the University of Georgia.

Gültepe, N., Salnur, S., Hossu, B., \& Hisar, O. (2011). Dietary supplementation with mannanoligosaccharides (MOS) from Bio-MOS enhances growth parameters and digestive capacity of gilthead sea bream (Sparus aurata). Aquaculture Nutrition, 17(5), 482-487. https://doi.org/ 10.1111/j.1365-2095.2010.00824.x

Haniffa, M. A., \& Marimuthu, K. (2004). Seed production and culture of snakehead. INFOFISH International, 2, 16-18.

Holben, W. E., Williams, P., Gilbert, M. A., Saarinen, M., Sarkilahti, L. K., \& Apajalahti, J. H. (2002). Phylogenetic analysis of intestinal 
microflora indicates a novel Mycoplasma phylotype in farmed and wild salmon. Microbial Ecology, 44, 175-185. https://doi.org/10. 1007/s00248-002-1011-6

Hoseinifar, S. H., Ahmadi, A., Raeisi, M., Hoseini, S. M., Khalili, M., \& Behnampour, N. (2016). Comparative study on immunomodulatory and growth enhancing effects of three prebiotics (galactooligosaccharide, fructooligosaccharide and inulin) in common carp (Cyprinus carpio). Aquaculture Research, 48(7), 3298-3307.

Hoseinifar, S. H., Khalili, M., \& Sun, Y.-Z. (2016). Intestinal histomorphology, autochthonous microbiota and growth performance of the oscar (Astronotus ocellatus Agassiz, 1831) following dietary administration of xylooligosaccharide. Applied Ichthyology, 32(6), 1137-1141.

Hoseinifar, S. H., Mirvaghefi, A., Amoozegar, M. A., Merrifield, D., \& Ringø, E. (2015). In vitro selection of a symbiotic and in vivo evaluation on intestinal microbiota, performance and physiological response of rainbow trout (Oncorhynchus mykiss) fingerlings. Aquaculture Nutrition, 23, 111-118. https://doi.org/10.1111/anu.12373

Hoseinifar, S. H., Safari, R., \& Dadar, M. (2017). Dietary sodium propionate affects mucosal immune parameters, growth and appetite related genes expression: Insights from zebrafish model. General and Comparative Endocrinology, 243, 78-83.

Hoseinifar, S. H., Sharifian, M., Vesaghi, M. J., Khalili, M., \& Esteban, M. Á. (2014). The effects of dietary xylooligosaccharide on mucosal parameters, intestinal microbiota and morphology and growth performance of Caspian white fish (Rutilus frisii kutum) fry. Fish \& Shellfish Immunology, 39(2), 231-236. https://doi.org/10.1016/j.fsi.2014.05.009

Hossain, M. K., Latifa, G. A., \& Rahman, M. M. (2008). Observations on induced breeding of snakehead murrel, Channa striatus (Bloch, 1793). International Journal of Sustainable Crop Production, 3, 65-68.

Ishibashi, N., Tatematsu, T., Shimamura, S., Tomita, M., \& Okonogi, S. (1985). Effect of water activity on the viability of freeze-dried bifidobacteria. Fundamentals and applications of freeze-drying to biology materials, drugs and foodstuffs (pp. 227-234). Paris, France: International Institute of Refrigeration.

Jamsari, A. F. J., Tan, M. P., \& Siti-Azizah, M. N. (2011). Genetic structure of the snakehead murrel, Channa striata (channidae) based on the cytochrome c oxidase subunit I gene: Influence of historical and geomorphological factors. Genetics and Molecular Biology, 34(1), 152-160. https://doi.org/10.1590/S1415-47572011000100026

Jian, Z., Yongjian, L., Lixia, T., Huijun, Y., Guiying, L., \& Donghui, X. (2012). Effects of dietary mannan oligosaccharide on growth performance, gut morphology and stress tolerance of juvenile Pacific white shrimp, Litopenaeus vannamei. Fish and Shell Fish Immunology, 33, 1027-1032.

Kim, D. H., Brunt, J., \& Austin, B. (2007). Microbial diversity of intestinal contents and mucus in rainbow trout (Oncorhynchus mykiss). Journal Applied Microbiology, 102, 1654-1664. https://doi.org/10.1111/j. 1365-2672.2006.03185.x

Kim, G. B., Seo, Y. M., Kim, C. H., \& Paik, I. K. (2011). Effect of dietary prebiotic supplementation on the performance, intestinal microflora, and immune response of broilers. Poultry Science, 90(1), 75-82. https://doi.org/10.3382/ps.2010-00732

Kleesen, B., Sykura, B., Zunft, H.-J., \& Blaut, M. (1997). Effects of inulin and lactose on faecal microflora, microbial activity and bowel habit in elderly constipated persons. American Journal of Clinical Nutrition, 65, 1397-1402.

Kruger, C. L., \& Mann, S. W. (2003). Safety evaluation of functional ingredients. Food and Chemical Toxicology, 41, 793-805.

Lara-Flores, M., Olvera-Novoa, M. A., Guzmán-Méndez, B. E., \& LópezMadrid, W. (2003). Use of the bacteria Streptococcus faecium and Lactobacillus acidophilus, and the yeast Saccharomyces cerevisiae as growth promoters in Nile tilapia (Oreochromis nilotic). Aquaculture, 216, 193-201.

Lewis, P. R., \& Knight, D. P. (1977). Staining methods for sectioned material. In A. M. Glauert (Ed.), Practical methods in electron microscopy
(Vol. 5, pp. 43-44). Amsterdum, The Netherlands: Elsevier/ North Holland Biomedical Press.

Liu, W., Marsh, T. L., Cheng, H., \& Forney, L. (1997). Characterization of microbial diversity by determining terminal restriction fragment length polymorphisms of genes encoding $16 \mathrm{~S}$ rRNA. Applied and Environmental Microbiology, 63, 4516-4522.

Llewellyn, M. S., Boutin, S., Hoseinifar, S. H., \& Derome, N. (2015). Teleost microbiomes: The state of the art in their characterization, manipulation and importance in aquaculture and fisheries. Frontiers in Microbiology, 207, 1-18.

MacFarlane, R., McLaughlin, J., \& Bullock, G. (1986). Quantitative and qualitative studies of gut flora in striped bass from estuarine and coastal marine environments. Journal of Wildlife Diseases, 22, 344 348.

Marsh, T. L. (2005). Culture-independent microbial community analysis with terminal restriction fragment length polymorphism. Methods in Enzymology, 397, 308-329.

Masanori, F., James, A. C., Kim, T. S., \& Marsh, T. L. (2013). Microbial community assembly and succession on lake sturgeon egg surfaces as a function of simulated spawning stream flow rate. Microbial Ecology, 66, 500-511. https://doi.org/10.1007/s00248-013-0256-6

Mäyrä-Mäkien, A., \& Bigret, M. (1993). Industrial use and production of lactic acid bacteria. In S. Salminen, \& A. Von Wright (Eds.), Lactic acid bacteria (pp. 65-95). New York, NY: Marcel Dekker.

Menne, E., Guggenbuhl, N., \& Roberfroid, M. B. (2000). Fn-type chicory inulin hydrolysate has a prebiotic effect in humans. Journal of Nutrition, 130, 1197-1199. https://doi.org/10.1093/jn/130.5.1197

Mitsuoka, T., Hidaka, H., \& Eida, T. (1987). Effect of fructo-oligosaccharides on intestinal microflora. Food/Nahrung, 31(5-6), 427-436. https://doi.org/10.1002/food.19870310528

Moen, F., Saeed, K., Mohammad, L., \& Faranaz, I. (2011). The investigation of Lactobacillus acidophilus as probiotics on growth performance and disease resistance of Rainbow Trout (Oncorhychus mykiss). American-Euroasian Journal of Scientific Research, 6(1), 32-38.

Muegge, B. D., Kuczynski, J., Knights, D., Clemente, J. C., Gonzalez, A., \& Fontana, L. (2011). Diet drives convergence in gut microbiome functions across mammalian phylogeny and within humans. Science, 332, 970-974. https://doi.org/10.1126/science.1198719

Munir, M. B., Hashim, R., Abdul Manaf, M. S., \& Nor, S. A. M. (2016). Dietary prebiotics and probiotics influence the growth performance, feed utilisation, and body indices of snakehead (Channa striata) fingerlings. Tropical Life Sciences Research, 27(2), 111-125. https://doi. org/10.21315/tlsr2016.27.2.9

Munir, M. B., Roshada, H., Yam, H. C., Terence, L. M., \& Azizah, S. (2016). Dietary prebiotics and probiotics influence growth performance, nutrient digestibility and the expression of immune regulatory genes in snakehead (Channa striata) fingerlings. Aquaculture, 460, 5968. https://doi.org/10.1016/j.aquaculture.2016.03.041

Nahid, A. M. (2015). Effect of Lactobacillus acidophilus and mannan oligosaccharide on growth performance, intestinal morphology, digestive enzymes activities, haematology and resistance of striped catfish (Pangasianodon hypophthalmus, Sauvage, 1878) juveniles against Aeromonas hydrophila. A doctoral thesis of School of Biological Sciences in Universiti Sains Malaysia.

Nayak, S. K. (2010). Role of gastrointestinal microbiota in fish. Aquaculture Research, 41, 1553-1573.

Ng, S. C., Hart, A. L., Kamm, M. A., Stagg, A. J., \& Knight, S. C. (2009). Mechanisms of action of probiotics: Recent advances. Inflammatory Bowel Diseases, 15(2), 300-310. https://doi.org/10.1002/ibd.20602

Nieminen, T. T., Vihavainen, E., Paloranta, A., Lehto, J., Paulin, L., Auvinen, P., ... Bjorkroth, K. J. (2011). Characterization of psychrotrophic bacterial communities in modified atmosphere-packed meat with terminal restriction fragment length polymorphism. International Journal of Food Microbiology, 144, 360-366. https://doi.org/10.1016/j.ijf oodmicro.2010.10.018 
Nino, B. (2013). Probiotics, prebiotics and the gut microbiota. ILSI Europe Concise Monograph Series. ILSI Europe a.i.s.b.I. D/2013/10.996/36. pp. 1-40, ISBN: 9789078637394 ISSN 2294-5490.

Noh, H., Han, K. I., Won, T. H., \& Choi, Y. J. (1994). Effect of antibiotics, enzymes, yeast culture and probiotics on the growth performance of Israeli carp. Korean Journal of Animal Sciences, 36, 480-486.

Philippe, G., \& Sylvie, R. (2010). Gl bacteria changes in animal models due to prebiotics. In R. R. Watson, \& R. V. Preedy (Eds.), Bioactive foods in promoting health: Probiotics and prebiotics (Chapter 33, pp. 553-570). Elsevier Inc. Retrieved from www.elsevierdirect.com

Quaak, F. C. A., \& Kuiper, I. (2011). Statistical data analysis of bacterial T-RFLP profiles in forensic soil comparisons. Forensic Science International, 210, 96-101.

Ramette, A. (2007). Multivariate analyses in microbial ecology. FEMS Microbiology Ecology, 62, 142-160.

Ringø, E., Bendiksen, H. R., Wesmajervi, M. S., Olsen, R. E., Jansen, P. A., \& Mikkelsen, H. (2000). Lactic acid bacteria associated with the digestive tract of Atlantic salmon (Salmo salar L.). Journal Applied Microbiology, 89, 317-322. https://doi.org/10.1046/j.1365-2672. 2000.01116.x

Ringø, E., Myklebust, R., Mayhew, T. M., \& Olsen, R. E. (2007). Bacterial translocation and pathogenesis in the digestive tract of larvae and fry. Aquaculture, 268, 251-264. https://doi.org/10.1016/j.aquacul ture.2007.04.047

Ringø, E., Sperstad, S., Myklebust, R., Mayhew, T. M., \& Olsen, R. E. (2006). The effect of dietary inulin on aerobic bacteria associated with hindgut of Arctic charr (Salvelinus alpinus L.). Aquaculture Research, 37, 891-897. https://doi.org/10.1111/j.1365-2109.2006. 01509.x

Ringø, E., Strøm, E., \& Tabachek, J. A. (1995). Intestinal microflora of salmonids: A review. Aquaculture Research, 26, 773-789.

Rodriguez-Estrada, U., Satoh, S., Haga, Y., Fushimi, H., \& Sweetman, J. (2013). Effect of inactivated Enterococcus faecalis and mannan oligosaccharide and their combination on growth, immunity and disease protection in rainbow trout. North American Journal of Aquaculture, 75(3), 416-428.

Shannon, C. E. (1948). A mathematical theory of communication. Bell System Technical Journal, 27, 379-423.

Sinh, L. X., \& Pomeroy, P. S. (2010). Current situation and challenges for the farming of Snakehead fish (Channa micropeltes and Channa striatus) in the Mekong Delta. Vietnam Aquaculture. Asia, XV(4), 11-18.

Snart, J., Bibiloni, R., \& Grayson, T. (2006). Supplementation of the diet with high-viscosity beta-glucan results in enrichment for lactobacilli in the rat cecum. Applied and Environmental Microbiology, 72, 19251931. https://doi.org/10.1128/AEM.72.3.1925-1931.2006

Spring, P., Wenk, C., Dawson, K. A., \& Newman, K. E. (2000). The effects of dietary mannanoligosaccharides on cecal parameters and the concentrations of enteric bacteria in the ceca of Salmonella-challenged broiler chicks. Poultry Sciences, 79, 205-211.

Talpur, A. D., Munir, M. B., Marry, A., \& Hashim, R. (2014). Dietary probiotics and prebiotics improved food acceptability, growth performance, haematology and immunological parameters and disease resistance against Aeromonas hydrophila in snakehead (Channa striata) fingerlings. Aquaculture Journal, 426-427, 14-20.

Thomas, C., \& Versalovic, J. (2010). Probiotics-host communication: Modulation of signalling pathways in the intestine. Gut Microbes, 1 , 148-163.

Waché, Y., Auffray, F., Gatesoupe, F. J., Zambonino, J., Gayet, V., Labbé, L., \& Quentel, C. (2006). Cross effects of the strain of dietary Saccharomyces cerevisiae and rearing conditions on the onset of intestinal microbiota and digestive enzymes in rainbow trout, Oncorhynchus mykiss, fry. Aquaculture, 258(1-4), 470-478.

Wang, Y. C., Yu, R. C., \& Chou, C. C. (2004). Viability of lactic acid bacteria and bifidobacteria in fermented soymilk after drying, subsequent rehydration and storage. International Journal of Food Microbiology, 93, 209-217.

Wee, K. L. (1982). Snakehead-their biology and culture. In R. Muir (Ed.), Recent advances in aquaculture (pp. 181-213). Boulder, CO: Westview.

Wu, G. D., Chen, J., Hoffmann, C., Bittinger, K., Chen, Y. Y., \& Keilbaugh, S. A. (2011). Linking long-term dietary patterns with gut microbial enterotypes. Science, 334, 105-108. https://doi.org/10.1126/science. 1208344

Wu, Z. X., Yu, Y. M., Chen, X., Liu, H., Yuan, J. F., Shi, Y., \& Chen, X. X. (2014). Effect of prebiotic konjac mannan-oligosaccharides on growth performance, intestinal microflora, and digestive enzyme activities in yellow catfish. Pelteobagrus Fulvidraco. Fish Physiology and Biochemistry, 40(3), 763-771.

Yarahmadi, P., Kolangi Miandare, H., \& Hoseinifar, S. H. (2016). Haemato-immunological and serum biochemical parameters, intestinal histomorphology and growth performance of rainbow trout (Oncorhynchus mykiss) fed dietary fermentable fibre (Vitacel®). Aquaculture Nutrition, 22(5), 1134-1142. https://doi.org/10.1111/anu. 12388

How to cite this article: Munir MB, Marsh TL, Blaud A, et al. Analysing the effect of dietary prebiotics and probiotics on gut bacterial richness and diversity of Asian snakehead fingerlings using T-RFLP method. Aquac Res. 2018;49:33503361. https://doi.org/10.1111/are.13799 